\title{
NR1D1 Gene
}

National Cancer Institute

\section{Source}

National Cancer Institute. NR1D1 Gene. NCI Thesaurus. Code C101738.

This gene plays a role in both transcriptional regulation and circadian rhythms. 